\title{
SISTEM INFORMASI PEMBAYARAN PASIEN RAWAT JALAN PADA RUMAH SAKIT ANGKATAN DARAT (RSAD) MATARAM
}

\author{
Juhartini ${ }^{1}$, Ahmad Yani ${ }^{2}$, Baiq Ratmini ${ }^{3}$,Lalu Moh. Nurkholis ${ }^{4}$ \\ STMIK Mataram $1,2,3$ \\ Universitas AMIKOM Yogyakarta1 \\ ASM Mataram 4 \\ juhartini.tini@gmail.com
}

\begin{abstract}
Abstrak - Dalam perkembangan ilmu pengetahuan dan teknologi, sistem informasi sangat berpengaruh dalam berbagai bidang. Dengan adanya sistem informasi dapat mempermudah dalam melakukan pengolahan data sehingga dapat menghemat waktu, ruang, dan biaya. Rumah Sakit Angkatan Darat (RSAD) Mataram adalah salah satu pusat pelayanan kesehatan yang berada di kota Mataram. Adapun kinerja sistem dalam pelayanan pasien yang berjalan di RSAD Mataram tersebut masih belum optimal karena pada pengolahan data masih menggunakan sistem manual. Banyak kendala yang dialami oleh pihak Rumah Sakit Angkatan Darat Mataram, diantaranya yaitu adanya kesalahan dalam melakukan input, penyimpanan data, serta dapat terjadi kerangkapan arsip pasien. Dalam Sistem Informasi Pembayaran Pasien Rawat Jalan terdapat beberapa form yakni form login, form menu utama yang berisi Menu Input Data, Menu Transaksi, Menu Laporan, dan Menu Keluar. Output yang dihasilkan berupa laporan pembayaran pasien rawat jalan dan kwitansi pembayaran pasien rawat jalan pada RSAD Mataram.
\end{abstract}

\section{Kata Kunci : Pembayaran, Pasien, Rawat Jalan, RSUD Mataram}

\section{Latar Belakang}

Dalam perkembangan ilmu pengetahuan dan teknologi, sistem informasi sangat berpengaruh dalam berbagai bidang. Dengan adanya sistem informasi dapat mempermudah dalam melakukan pengolahan data sehingga dapat menghemat waktu, ruang, dan biaya. Untuk meningkatkan pelayanan kesehatan yang baik bagi masyarakat, perlu adanya perubahan dalam hal sistem yang digunakan agar lebih efektif dan efisien. Pengolahan data untuk pelayanan kesehatan didalam masyarakat sangat penting. Dengan adanya pengolahan data dapat dihasilkan sebuah informasi untuk membantu proses pelayanan kesehatan sehingga dapat menyajikan segala kebutuhan informasi layanan kesehatan bagi masyarakat.

Rumah Sakit Angkatan Darat (RSAD) Mataram adalah salah satu pusat pelayanan kesehatan yang berada di kota Mataram. Adapun kinerja sistem dalam pelayanan pasien yang berjalan di RSAD Mataram tersebut masih belum optimal karena pada pengolahan data masih menggunakan sistem manual. Banyak kendala yang dialami oleh pihak Rumah Sakit Angkatan Darat Mataram, diantaranya yaitu adanya kesalahan dalam melakukan input, penyimpanan data, serta dapat terjadi kerangkapan arsip pasien. Sehingga pengolahan data menjadi tidak efektif dan efisien. Hal tersebut dapat menghambat jalannya laporan pembayaran dan kelancaran dalam pelayanan kepada pasien. Kesalahan perhitungan pembayaran merupakan contoh masalah yang sering dihadapi dalam pembayaran pasien rawat jalan. Rumah Sakit Angkatan Darat Mataram selaku instansi pemerintah dalam melakukan pengolahan data pembayaran pasien rawat jalan belum memadukan antara datadata di bagian pembayaran pasien rawat jalan dengan bagian keuangan, dan masih menggunakan sistem manual. Hal ini menyebabkan terjadinya redudansi data, proses perhitungan pembayaran pasien rawat jalan tidak efektif dan efisien, sehingga penyajian informasi tidak bisa diterima tepat pada waktunya. Adapun input dan output pada sistem informasi pembayaran pasien rawat jalan ini yaitu Inputnya meliputi data pasien, data dokter, data penyakit, data poli, data pemeriksaan pasien dan data pembayaran pasien rawat jalan. Output yang dihasilkan berupa laporan data pasien, laporan pembayaran pasien rawat jalan dan kwitansi pembayaran pasien rawat jalan pada RSAD Mataram. Sedangkan manfaat dengan adanya sistem informasi pembayaran pasien rawat jalan ini antara lain dapat mempermudah pihak RSAD Mataram dalam pembayaran pasien rawat jalan. Serta dapat melaksanakan kegiatan layanan kesehatan menjadi lebih efektif dan memberikan kemudahan dalam penggunaan sistem layanan kesehatan dengan pemrograman komputer

\section{Kajian Pustaka}

\section{a. Pengertian Sistem}

Menurut Lucas dalam Kumorotomo (2002:25) menyatakan bahwa sistem adalah suatu kumpulan atau himpunan dari usur, komponen/variabel-variabel yang terorganisasi, saling berinteraksi, saling tergantung satu sama lain dan terpadu. Sedangkan menurut Tata Sutabri (2012:9), Secara umum sistem dapat diartikan sebagai kumpulan atau himpunan dari unsur, komponen, atau variable yang terorganisir, saling berintraksi, saling tergantung satu sama lain dan terpadu. Teori sistem secara umum yang pertama kali diuraikan oleh Kenneth Boulding, terutama menekan pentingnya perhatian terhadap setiap bagian yang membentuk sebuah sistem, kecenderungan manusia yang mendapat tugas memimpin suatu organisasi terlalu memusatkan 
perhatian pada salah satu komponen saja dari sistem organisasi.

Berdasarkan buku yang berjudul "Sistem Informasi dan Implementasinya" oleh I Putu Agus Eka Pratama (2014:7), Sistem dapat didefinisikan sebagai sekumpulan prosedur yang saling berkaitan dan saling terhubung untuk melakukan suatu tugas bersama-sama.

\section{b. Pengertian Informasi}

Berdasarkan buku yang berjudul "Sistem Informasi dan Implementasinya" oleh I Putu Agus Eka Pratama (2014:9), Informasi merupakan hasil pengolahan data dari satu atau berbagai sumber, yang kemudian diolah, sehingga memberikan nilai, arti dan manfaat.

Menurut Hartono (2005:8) "Informasi adalah data yang diolah menjadi bentuk yang lebih berguna dan lebih berarti bagi yang menerimanya". Informasi dapat diperoleh dari sistem informasi (Information System).

Menurut Davis dalam Abdul Kadir (2003:28) Informasi adalah data yang telah diolah menjadi sebuah bentuk yang berarti bagi penerimanya dan bermanfaat bagi pengambilan keputusan saat ini atau saat mendatang.

\section{c. Pengertian Sistem Informasi}

Menurut Oetomo (2006:11) Sistem informasi refrensi kumpulan komponen yang saling berhubungan satu sama lain yang membentuk satu kesatuan untuk mengintegrasikan data, memproses dan menyimpan serta mendistribusikan informasi. Sedangkan menurut McLeod definisi dari informasi adalah data yang diolah menjadi bentuk lebih berguna dan lebih berarti bagi yang menerimanya. (Yakub, 2012:8)

Menurut Lucas dalam Kumorotomo (2002:30) menyatakan bahwa sistem informasi adalah sekumpulan prosedur organisasi yang pada saat dilaksanakan akan memberikan informasi bagi pengambil keputusan dan atau untuk mengendalikan informasi.

Berdasarkan buku yang berjudul "Sistem Informasi dan Implementasinya" oleh I Putu Agus Eka Pratama (2014:9), Informasi merupakan hasil pengolahan data dari satu atau berbagai sumber, yang kemudian diolah, sehingga memberikan nilai, arti dan manfaat

\section{d. Pembayaran Pasien Rawat Jalan}

Pembayaran adalah proses atau cara membayar " Jadi, pembayaran adalah tata cara membayar dimana terjadi pemberian sejumlah uang dari seseorang kepada orang lain atas jasa atau barang yang diterima atau dibelinya

Pasien adalah seseorang yang kondisi badannya tidak pada semestinya atau kurang baik dimana orang tersebut dirawat oleh seorang dokter.

Rawat jalan adalah pelayanan pengobatan di fasilitas pelayanan kesehatan dengan tidak harus menginap di fasilitas pelayanan kesehatan tersebut baik didalam gedung dan diluar gedung. [http://www.dinkesjatim.go.id definisi rawat jalan (23 April 2008)]. Jadi, pengertian rawat jalan ada lah pelayanan kesehatan yang diberikan oleh dokter dan tidak mengharuskan pasiennya untuk menginap.

Diagnosa adalah penentuan jenis penyakit dengan cara meneliti atau memeriksa gejala gejalanya . Jadi, diagnosa adalah penentuan jenis penyakit oleh seorang ahli kesehatan atau dokter yang dilakukan melalui proses pemeriksaan gejala- gejala yang dialami oleh pasien.

\section{e. Pengertian Data}

Data menurut Kadir (2001:19) adalah fakta mengenai objek, orang dan lainlain. Data dapat dinyatakan dengan nilai (angka, deretan karakter atau simbol.

\section{f. Pengertian Database}

Menurut Nana Suarna (2004) Database adalah kumpulan file-file yang mempunyai kaitan antara satu file dengan file yang lain sehingga membentuk suatu bangunan data untuk menginformasikan satu perusahaan instansi dalam batasan tertentu.

Sedangkan menurut Syahroni (2003), database adalah kumpulan dari data yang saling berhubungan, tersimpan di perangkat keras komputer dan digunakan perangkat lunak untuk memanipulasinya.

Database merupakan salah komponen yang penting dalam sistem informasi, karena merupakan basis dalam menyediakan informasi bagi para pemakai.

\section{g. Pengertian DFD}

Menurut Budi Sutedjo dalam buku perancangan dan pembangunan Sistem Informasi (2009:117) menjelaskan: "Data flow diagram meruapakan peralatan yang berfungsi untuk menggambarkan secara rinci mengenai sistem sebagai jaringan kerja antar fungsi yang berhubungan satu sama lain dengan menunjukkan dari dan kemana data mengalir serta penyimpanannya".

\section{h. Pengertian ERD}

Pemodelan ER-Diagram awalnya adalah cara menyajikan design suatu table database di atas kertas yang nantinya model tersebut akan berguna untuk pengembangan databasenya. ERDiagram ini terdiri dari komponen-komponen seperti entitas, atribut dan relasi antar entitasnya. Atribut dalam hal ini bertugas sebagai penjelas entitas, sedangkan relasi menggambarkan hubungan yang terjadi di antara entitas (Sutanta, 2004:37)

\section{i. Normalisasi}

Menurut Sintha Setyaningrum (2013:35) menurut Conolly dan Begg, normalisasi adalah sebuah teknik untuk menghasilkan sejumlah 
relasi dengan sifat-sifat yang diinginkan sehingga dapat memenuhi kebutuhan data pada perusahaan. Kadir (2002:42), normalisasi adalah suatu proses untuk mengubah suatu tabel yang memiliki masalah tertentu ke dalam dua buah tabel atau lebih, yang tidak lagi memiliki masalah tertentu ke dalam dua buah tabel atau lebih, yang tidak lagi memiliki masalah tersebut. Masalah tersebut biasanya merupakan suatu ketidak konsistenan (tidak normal) apabila dilakukan penghapusan (delete), pengubahan (update) dan pembacaan (retrieve) pada suatu basis data.

\section{j. Bagan Alir (Flowchart)}

Menurut Yakub (2012) Flowchart adalah penggambaran secara grafik dari langkahlangkah dan urut-urutan prosedur dari suatu program. Flowchart menolong analis dan programmer untuk memecahkan masalah ke dalam segmen-segmen yang lebih kecil dan menolong dalam menganalisis alternatif-alternatif lain dalam pengoperasian.

Berdasarkan buku yang berjudul "Logika \& Algoritma Dasar Menggunakan Bahasa C++" oleh Indarwoko Kurniadi (2013:161), Flowchart dalam bahasa Indonesia diterjemahkan sebagai Diagram Alir. Dari dua kata ini, maka dapat kita bayangkan bahwa Flowchart itu berbentuk diagram yang bentuknya dapat mengalirkan sesuatu. Flowchart adalah penggambaran secara grafik dari langkah-langkah dan urut-urutan prosedur dari suatu program

\section{Perancangan Sistem/Metode Penelitian}

\section{a. Metode Pengembangan Perangkat Lunak}

Menurut Pressman (2010), model waterfall adalah model klasik yang bersifat sistematis, berurutan dalam membangun software. Waterfall adalah suatu metodologi pengembangan perangkat lunak yang mengusulkan pendekatan kepada perangkat lunak sistematik dan sekuensial yang mulai pada tingkat kemajuan sistem pada seluruh system enginering, analysis, design, code, testing dan maintenance. Pada gambar 1 dibawah ini merupakan gambar dari Metode Siklus Daur Hidup/Model Squensial/Waterfall.

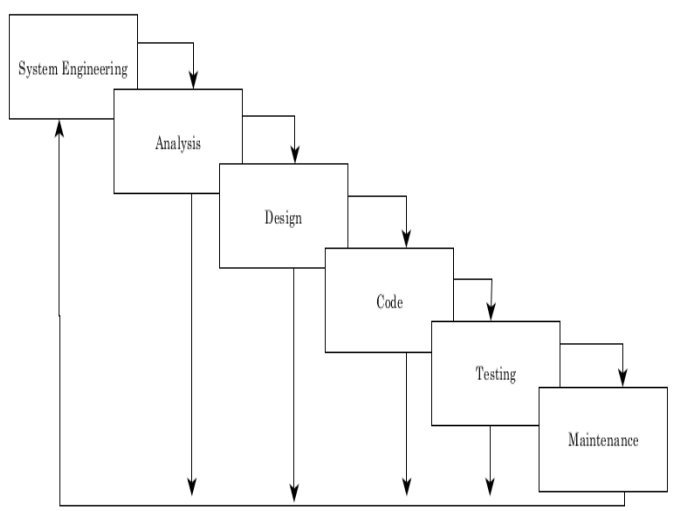

Gambar 1. Metode Waterfall

b. Sekilas Tentang RSAD Mataram

Sebagai Badan pelaksana (Kesehatan Daerah Militer) Kesdam IX/Udayana, Rumah Sakit Angkatan Darat (RSAD) Mataram melaksanakan kegiatan berdasarkan Program kerja dan anggaran Kesdam IX/Udayana selaku pembina fungsi teknis maupun organik, serta melaksanakan kegiatan non program sesuai petunjuk / perintah Danrem 162 Wira Bhakti dalam rangka mendukung tugas pokok Korem 162/Wira Bahkti.

Pada tanggal 28 Oktober 1985 dengan Surat Keputusan Kasad Nomor Skep / 76 / X / 1985 nama Rumah Sakit Korem 162 / Wira Bhakti berubah menjadi Rumah Sakit Tk IV 09.07.02. Mataram yang beralamat di Jl. Hoscokroaminoto No. 07 Mataram sebelah Barat Lembaga Pemasyarakatan Propinsi NTB.

c. Sistem Baru (Alternative)

Flow map sistem baru untuk sistem informasi pembayaran pasien rawat jalan yang diusulkan pada RSAD Mataram. Adapun rincian dari flow map ini sebagai berikut :

1. Pasien melakukan pendaftran di bagian administrasi

2. Bagian administrasi menginputkan data pasien kedalam aplikasi dan hasilnya disimpan ditabel data pasien dan menyimpannya dalam database.

3. Bagian administrasi membuat laporan data pasien yang akan diserahkan kepoli untuk pemeriksaan pasien kemudian dari hasil pemeriksaan pasien tersebut, bagian administrasi menginputkan kedalam database

4. Bagian administrasi mencetak laporan pembayaran pasien rawat jalan dan kwitansi pembayaran pasien rawat jalan.

5. Bagian administrasi menyerahkan kwitansi pembayaran kepada pasien dan menyimpan laporan pembayaran sebagai arsip.

Flow map ini sistem baru pada sistem informasi pembayaran pasien rawat jalan pada RSAD Mataram dapat dilihat pada gambar 2 berikut. 


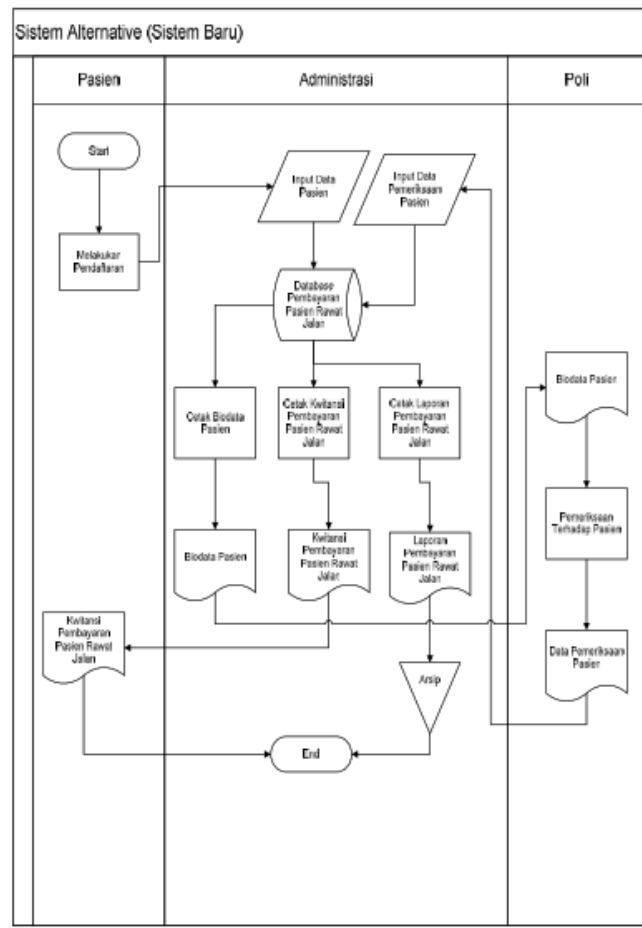

Gambar 2. Sistem Baru (Alternative)

\section{d. Diagram Context}

Diagram context menggambarkan sistem dalam satu lingkaran dan hubungan dengan entitas luar. Lingkaran tersebut menggambarkan keseluruhan proses dalam sistem informasi pembayaran pasien rawat jalan dimana bagian administrasi bertugas menginput data pasien, data poli, data dokter, data penyakit, data pemeriksaan dan data pembayaran ke dalam sistem informasi pembayaran pasien rawat jalan. Kemudain pada sistem informasi ini menghasilkan kwitansi pembayaran yang diberikan ke pasien dan laporn biodata pasien yang diberikan ke masing-masing poli yang dituju. Laporan pembayaran diterima oleh bagian administrasi yang disimpan sebagai asrip. Berikut adalah diagram context yang ada pada sistem informasi pembayaran pasien rawat jalan pada RSAD Mataram dapat dilihat pada gambar 3 dibwah ini.

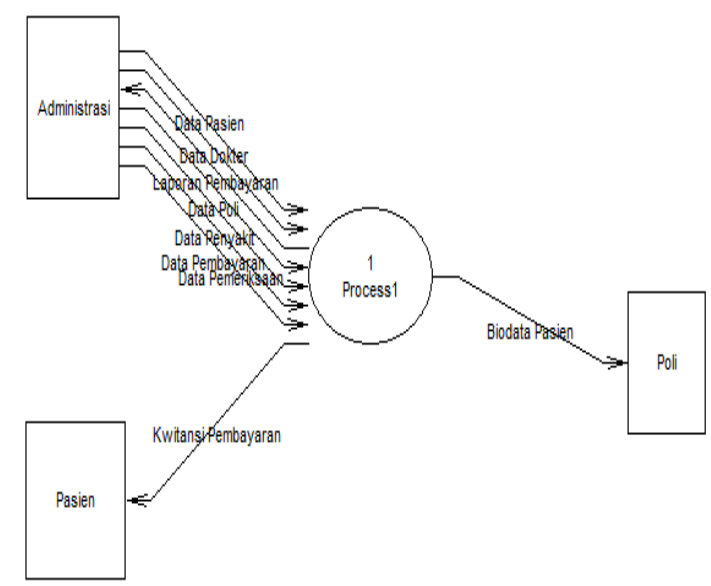

Gambar 3. Diagram Context

\section{e. Relasi Database}

Relasi database ini disesuaikan dengan diagram hubungan entitas (ERD) dimana pada relasi database ini menjelaskan tentang relasi dari masing-masing table yang mana table pasien, penyakit, poli, dokter tertuju pada table pemeriksaan dan table pemeriksaan tertuju pada table pembayaran. Berikut pada gambar 4 merupakan relasi database dari Sistem Informasi pembayaran pasien rawat jalan pada RSAD Mataram.

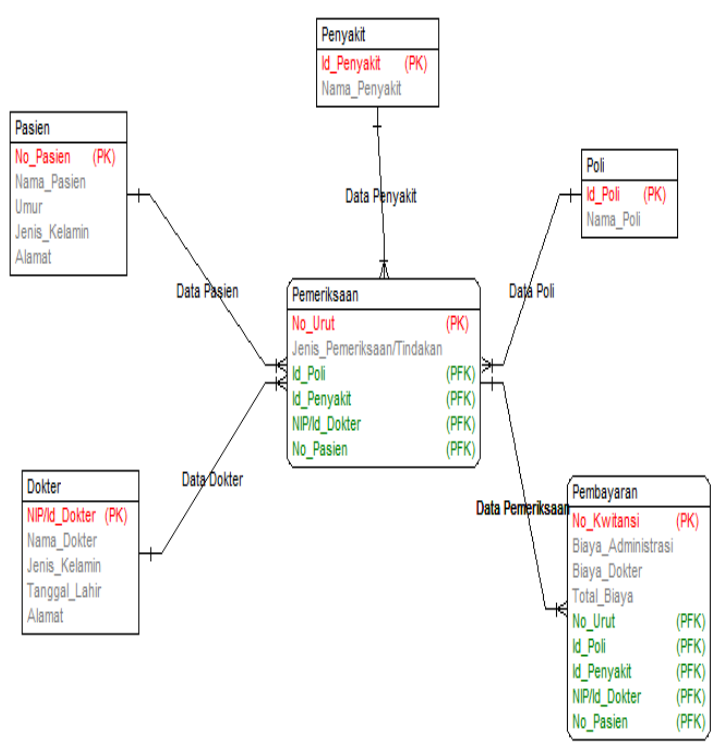

Gambar 4. Relasi Database

\section{f. Desain Form Menu Utama}

Pada Form Menu Utama terdapat beberapa menu, diantaranya: menu data, laporan, info dan keluar, menu data berisikan data siswa, data iuran, dan data transaksi, sedangkan pada menu laporan terdapat laporan transaksi pembayaran SPP slip transaksi. Desain form menu utama dapat dilihat pada gambar 5 diberikut ini.

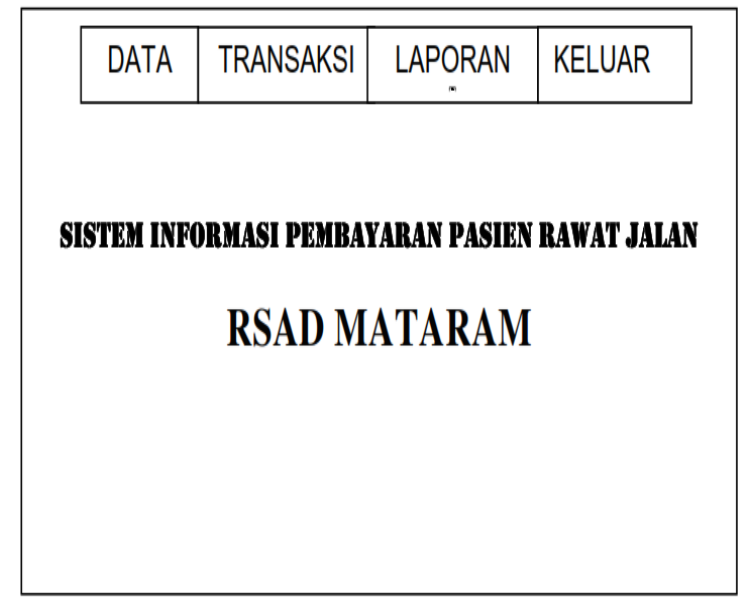

Gambar 5. Desain Form Menu Utama

\section{g. Desain Form Pembayaran Pasien}

Pada Form pembayaran pasien terdapat beberapa field yang harus diisi nantinya oleh 
bagian administrasi seperti no kwitansi, no urut, tanggal, biaya administrasi dan biaya dokter. Pada desain form pembayaran ini juga dilengkapi dengan tujuh button yaitu button add, simpan, edit, batal, hapus, keluar dan cetak kwitansi. Desain form pembayaran pasien dapat dilihat pada gambar 6 diberikut ini.

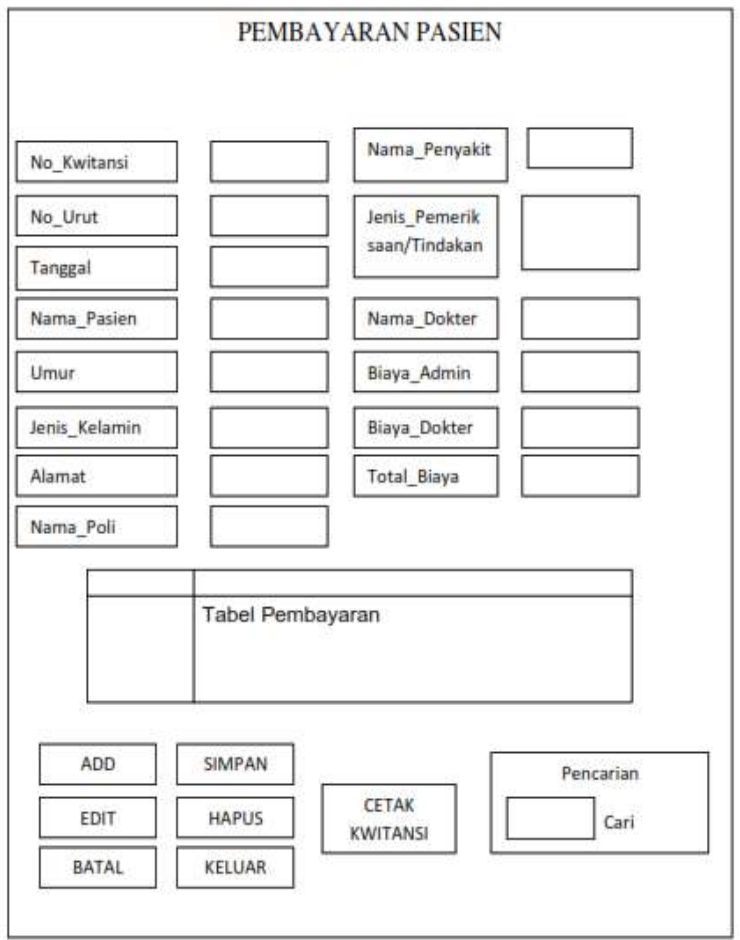

Gambar 6. Desain Form Pembayaran Pasien

\section{h. Desain Kwitansi Pembayaran Pasien}

Pada kwitansi pembayaran pasien yang terdapat pada gambar 7 dibawah ini menunjukkan desain dari kwitansi pembayaran pasien pada sistem informasi pembayaran pasien rawat jalan pada RSAD Mataram. Pada desain kwitansi ini memunculkan data psien dan data pembayaran yang telah dilakukan oleh pasien.setiap pasien menerima 1 lembar kwitansi pembayaran sebagai bukti telah melakukan pembayaran untuk rawat jalan.

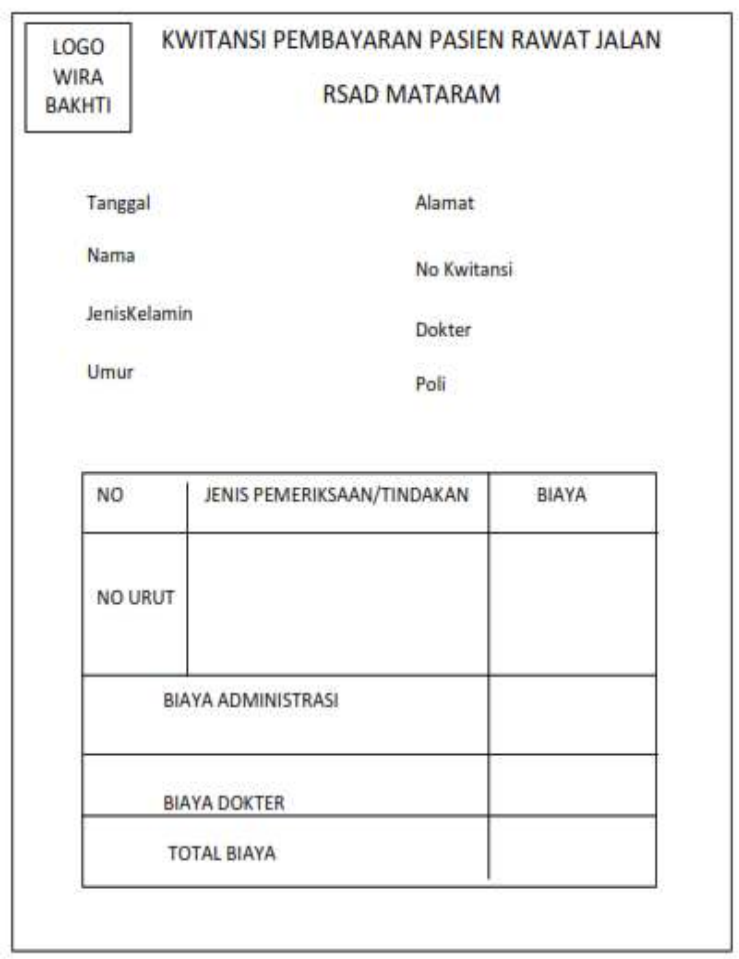

Gambar 7. Desain Kwitansi Pembayaran Pasien

\section{Implementasi Sistem dan Hasil}

Pada tahapan ini akan di terangkan secara singkat penggunaan program Sistem Informasi Pembayaran Pasien Rawat Jalan pada Rumah Sakit Angkatan Darat (RSAD) Mataram beserta cara penggunaan dan tombol perintah didalamnya.

\section{a. Form login}

Menu login ini berfungsi sebagai penentu bagi para pengguna program aplikasi, sehingga tidak sembarang orang bisa mengakses program ini. Pada menu login ini terdapat dua tombol, yaitu tombol "Login" yang berfungsi untuk masuk ke menu utama dan tombol "Logout" yang berfungsi untuk keluar dari menu login sekaligus untuk keluar dari sistem informasi. Form Login dapat dilihat pada gambar 8 dibawah ini.

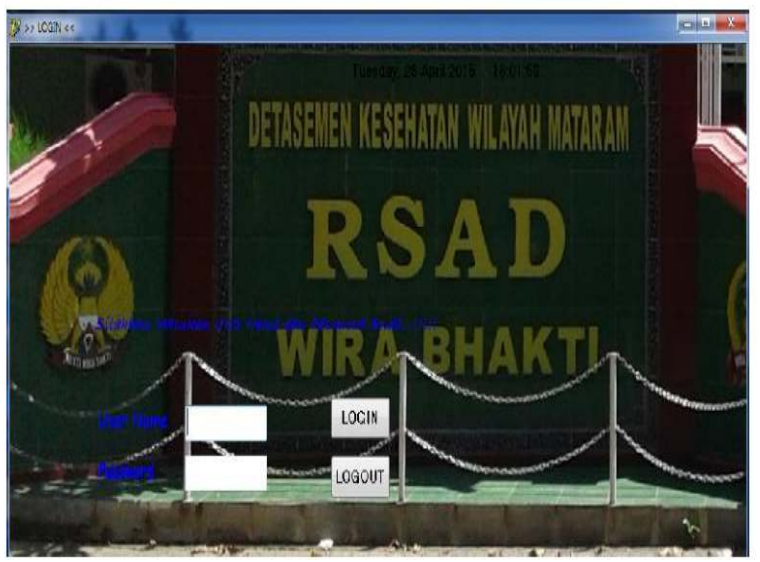

Gambar 8. Form Login

\section{b. Form Pembayaran Pasien}

Form input data pembayaran pasien digunakan untuk menginputkan nomer kwitansi 
pasien, nomer urut pasien, nama pasien, umur pasien, jenis kelamin pasien, alamat pasien, nama poli, nama penyakit, jenis pemeriksaan/tindakan, nama dokter, biaya administrasi, biaya dokter dan total biaya. Dimana dalam form ini terdapat enam buah bottun yang memiliki fungsi atau perintah yang berbeda pada tiap button diantaranya.

1. Tombol ADD

Tombol ini berfungsi untuk membuat record baru terhadap data pembayaran yang akan dinputkan kedalam sistem.

2. Tombol Simpan

Tombol ini digunakan untuk menyimpan semua data pembayaran yang sudah diinputkan kedalam sistem.

3. Tombol Batal

Tombol ini digunakan untuk membatalkan perintah yang sudah diberikan.

4. Tombol Hapus

Tombol ini berfungsi untuk menghapus data yang sudah diinputkan.

5. Tombol Edit

Tombol edit digunakan untuk merubah data pembayaran yang telah disimpan dalam database.

6. Tombol Keluar

Tombol keluar digunakan untuk mengkahir atau keluar dari form data pembayaran dan kembali kemenu utama.

7. Cetek Kwitansi

Tombol cetak kwitansi digunakan untuk mencetak kwitansi pembayaran pasien yang mana kwitansi tersebut akan diberikan kepada pasien.

Form pembayaran pasien dapat dilihat pada gambar 9 dibawah ini.

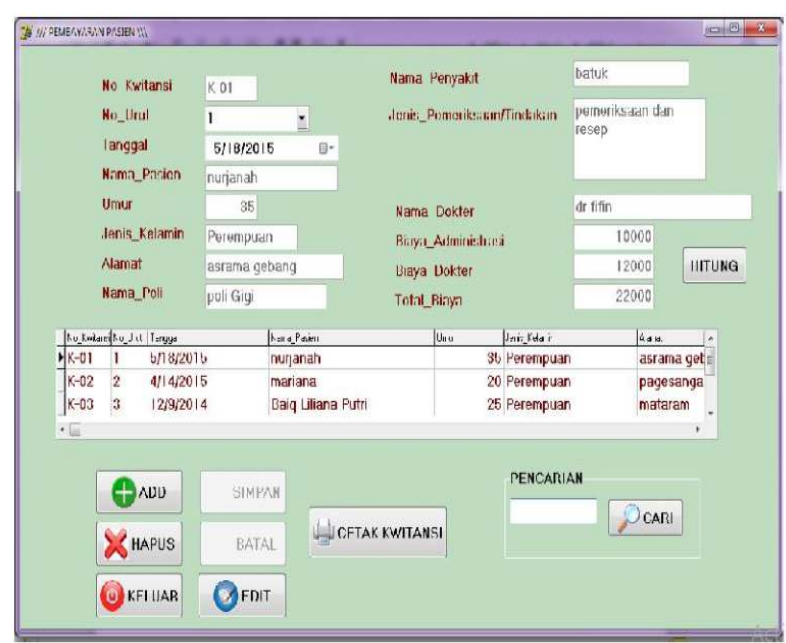

Gambar 9. Form Pembayaran Pasien

\section{c. Laporan Pembayaran Pasien}

Laporan ini digunakan untuk melihat sekaligus mencetak laporan data pembayaran pasien rawat jalan perbulan atau setiap bulannya. Untuk melihat atau melakuan pencetakan terhadap no kwitansi, tanggal, nama pasien, alamat, jenis kelamin, nama poli, nama dokter, nama penyakit, dan total biaya. Laporan pembayaran psien rawat jalan pada RSAD Mataram dapat dilihat pada gambar 10 dibawah ini.

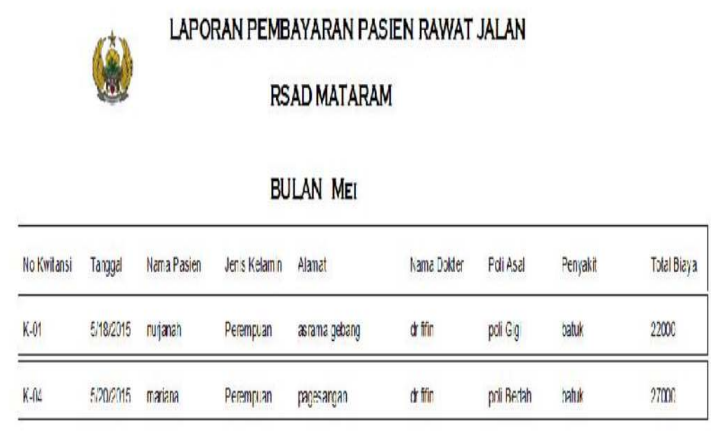

Gambar 10. Laporan Pembayaran Pasien

\section{d. Flowchart Form Login}

Flowchart form login pada gambar 11 dibawah ini menjelaskan tentang alur kerja dari sistem informasi pembayaran pasien rawat jalan pada RSAD Mataram pada form login. Dimana dijelaskan mulai dari memasukan user dan password jika user dan password benar dan klik button masuk maka akan masuk ke dalam menu utama, namun jika user dan password salah maka akan kembali ke form login. Jika mengklik button Logout maka akan kembali ke form login

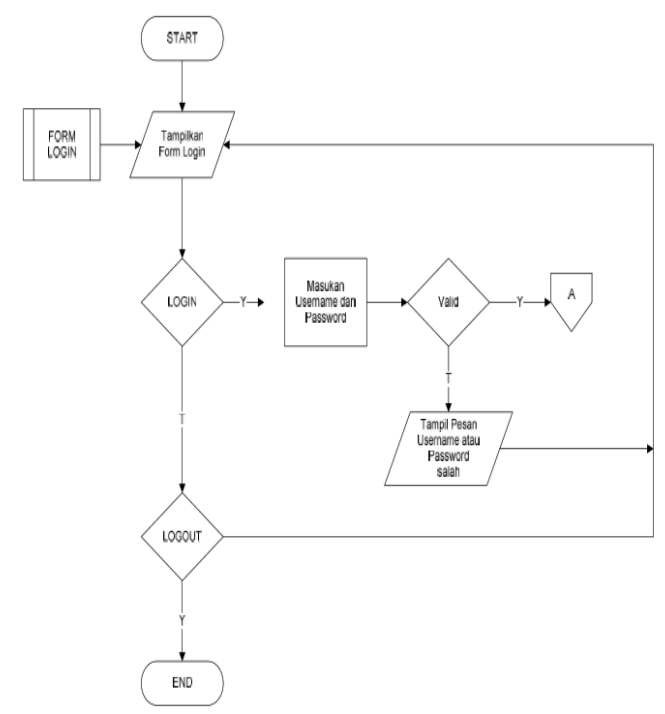

Gambar 11. Flowchart Form Login

\section{e. Flowchart Form Pembayaran Pasien}

Flowchart form pembayaran pasien pada gambar 12 dibawah ini menjelaskan tentang alur kerja dari sistem informasi pembayaran pasien rawat jalan pada RSAD Mataram pada form pembayaran pasien. Dimana pada flowchat ini menjelaskan alur dari masing-masing button mulai dari button add sampai ke button cetak kwitansi pembayaran dan button keluar. Contohnya seperti button add dimana jika memilih button add maka bagan administrasi akan mengisi data pembayaran dan akan memilih 
button simpan atau batal. Jika memilih button simpan maka data pembayaran akan tersimpan ke dalam database dan bias dilakukan pencetakan kwitansi pembayaran, namun jika memilih button batal maka data pembayaran yang diinputkan akan hilang dan form akan menjadi kosong kembali.

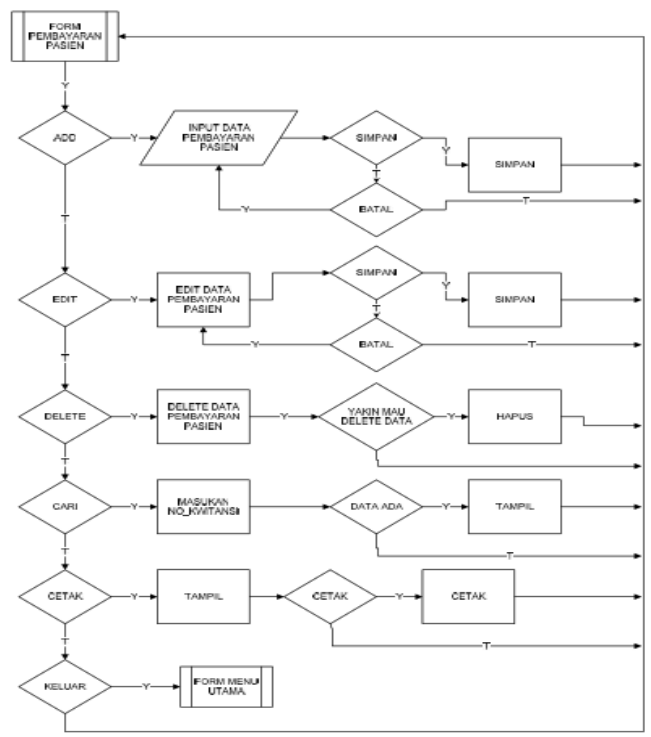

Gambar 12. Flowchart Form Pembayaran Pasien

\section{Kesimpulan}

Berdasarkan uraian dan penjelasan di atas, maka dapat disimpulkan beberapa hal yaitu Sistem Informasi Pembayaran Pasien Rawat Jalan ini menggunakan metode pengembangan perangkat lunak Waterfall sampai dengan coding dan testing. Perancangan sistem dilakukan dengan Flowchart sistem dan Data Flow Diagram (DFD), sedangkan perancangan database menggunakan Normalisasi dan Entity Relationship Diagram. Pada sistem informasi pemabayar pasien rawat jalan ini juga terdapat beberapa form yakni form login, form menu utama yang berisi Menu Input Data, Menu Transaksi, Menu Laporan, dan Menu Keluar. Output yang dihasilkan berupa laporan pembayaran pasien rawat jalan dan kwitansi pembayaran pasien rawat jalan pada RSAD Mataram.

\section{Daftar Pustaka}

Budi Sutedjo Dharma Oetomo, S.Kom., MM, "Pengembangan Sistem Informasi Perguruan Tinggi Raharja Berbasis information Engineering", STTi Benarif Indonesia, Jakarta, 2006.

Kadir, Abdul \& Terra Ch. Triwahyuni. 2005. Pengenalan Teknologi Informasi. Penerbit Andi Yogyakata.

Kumorotomo, Wahyudi dan Subando Agus Margodo. 2004. Sistem Informasi Manajemen. Penerbit Gadjah Mada University Press.

Pratama, E, I Putu Agus, 2014. Sistem Informasi dan Implementasinya. Bandung : Informatika Bandung.
Simarmata, Jener. 2010. Rekayasa Perangkat Lunak. Penerbit Andi Yogyakarta.

Sintha Setyaningrum. 2013. Konsep dan Perancangan Basis Data. Yogyakarta: Skripta Media Creative.

Suarna, Nana. 2004. Pedoman Panduan Praktikum Microsoft Access 2002. Penerbit Yrama Widia 2004.

Sutabri, Tata, 2012. Konsep Sistem Informasi. Penerbit Andi Yogyakarta

Yakub: 2012.Pengantar Sistem Informasi. Yogyakarta : Graha IImu. 